\title{
Media Pembelajaran Interaktif Perangkat Keras Komputer
}

\author{
Muhamad Arpan ${ }^{1 *}$ dan Sadikin ${ }^{1}$ \\ ${ }^{1}$ Program Studi Pendidikan TIK, Fakultas Pendidikan MIPA dan Teknologi, IKIP PGRI Pontianak \\ *e-mail : arpanmuhamad@gmail.com
}

\begin{abstract}
Abstrak - Tujuan penelitian melakukan pengembangan media pembelajaran yang interaktif berbasis desktop. Jenis penelitian yaitu penelitian dan pengembangan ADDIE. Subjek penelitian siswa kelas XA Jurusan TKJ. Teknik pengumpul data dengan wanwancara, angket, observasi, serta dokumentasi. Statistik deskriptif digunakan sebagai teknik analisis data. Hasil penelitian yaitu: Analysis, meliputi Analisis Mata Pelajaran; Analisis Pengguna; Analisis Materi dan Media; serta Analisis Sarana dan Prasarana. Design, meliputi Desain Materi; Desain GBIM; Storyboard; dan Flowchart. Develop, media yang dikembangkan berisi gambar, suara, dan teks. Implement, media diterapkan ke subjek penelitian. Evaluate, media divalidasi ahli materi dan media masuk kategori "Sangat Baik" serta respons subjek penelitian terhadap media tersebut masuk kategori "Sangat Baik." Berdasarkan hasil validasi dan respons subjek penelitian, maka kesimpulannya adalah media yang dikembangkan valid dan layak untuk digunakan.
\end{abstract}

Kata Kunci : media pembelajaran, interaktif, desktop

\begin{abstract}
The research purpose was to develop a desktop-based interactive learning media. This type of research was the research and development of the ADDIE model. The research subjects were students of class XA TKJ. Data collection techniques with an interview, questionnaires, observations, and documentation. Descriptive statistics were used as data analysis techniques. The results of the research were: Analysis, including Analysis of Subjects; User Analysis; Material and Media Analysis; and Analysis of Facilities and Infrastructure. Design, including Material Design; GBIM design; Storyboard; and Flowchart. Develop, the developed media contains images, sound, and text. Implement, the media is applied to the research subject. Evaluate, the media was validated by the material and the media experts was categorized as "Very Good" and the responses of the research subjects to the media was categorized as "Very Good."
\end{abstract}

Keywords : learning media, interactive, desktop

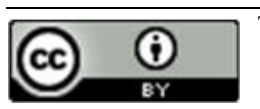

This is an open access article distributed under the Creative Commons 4.0 Attribution License

\section{Pendahuluan}

Pemahaman siswa terhadap materi yang diajarkan salah satunya dipengaruhi oleh media yang digunakan dalam pembelajaran. Penggunaan media pembelajaran yang interaktif membuat siswa mendengarkan materi yang dijelaskan, bahkan siswa melihat dan melakukan sehingga terjadi peningkatan pemahaman dan hasil belajar siswa [1-8]. Kemampuan siswa dalam pemahaman materi dengan membaca memberikan kontribusi sebesar 10 persen, dengan mendengar memberikan kontribusi sebesar 20 persen, dengan melihat memberikan kontribusi sebesar 30 persen, dengan mendengar dan melihat memberikan kontribusi sebesar 50 persen, dengan mengatakan memberikan kontribusi sebesar 70 persen, serta dengan melakukan memberikan kontribusi sebesar 90 persen [9].

Informasi [9] tersebut berarti bahwa menggunakan media pembelajaran tanpa audiovisual, maka proses pembelajaran tidak optimal dalam memberikan pemahaman ke siswa tentang materi pelajaran yang disampaikan. Penggunaan media menggunakan audio-visual pada proses pembelajaran memberikan kontribusi yang lebih besar terhadap pemahaman siswa akan materi yang disampaikan. Penggunaan media dengan audiovisual akan berimplikasi pada peningkatan hasil belajar ataupun motivasi belajar siswa [10-17]. 
Berdasarkan hasil pengamatan peniliti di SMK Negeri 7 Pontianak, diperoleh fakta bahwa masih ada guru yang tidak menerapkan media pembelajaran interaktif dalam proses pembelajaran, sedangkan guru tersebut memiliki kompetensi terhadap penggunaan media interaktif, khususnya guru mata pelajaran produktif TKJ (Teknik Komputer dan Jaringan) sangat memiliki kemampuan, baik dari segi pengoperasian media maupun dalam pembuatan media pembelajaran interaktif.

Proses penyampaian materi pada mata pelajaran Pengenalan Perangkat Keras Komputer hanya berupa teks atau gambar dengan tampilan yang kurang menarik. Hal tersebut membuat siswa bosan, jenuh, dan menimbulkan persepsi yang berbeda-beda dalam pemahaman materi yang diajarkan. Siswa kesulitan dalam menghafal namanama serta fungsi perangkat keras komputer. Dampak lainnya adalah waktu pembelajaran akan habis terpakai untuk menjelaskan secara berulang nama serta fungsi masing-masing komponen perangkat keras komputer tersebut.

Tingkat kesulitan dalam pemahaman nama dan fungsi perangkat keras komputer adalah dikarenakan bentuk dan fungsinya berbeda-beda sehingga posisi setiap perangkat tersebut harus ditempatkan sesuai dengan tempatnya, begitu juga dalam pemasangan kabel-kabel yang terdapat dalam perangkat keras komputer tersebut juga berbeda-beda fungsinya. Apabila siswa tidak memahami nama dan fungsi setiap perangkat keras komputer, maka siswa akan kesulitan pada saat melakukan praktik perakitan komputer. Siswa akan sulit melakukan praktik merakit komputer tanpa mengenal dengan baik nama dan fungsi masingmasing setiap komponen perangkat keras komputer dan jika siswa merakit tanpa mengenal dengan baik nama serta fungsi komponennya, maka akan menyebabkan kerusakan pada komponen perangkat keras komputer tersebut.

Hasil penelitian yang dilakukan [18] memperlihatkan bahwa multimedia pembelajaran interaktif yang dikembangkan untuk mahasiswa Medical Laboratory Technology di STIKes Perintis Padang berada pada kategori "Sangat Valid." Penelitian tersebut hanya membahas tentang validitas media pembelajaran yang dikembangkan, tidak membahas tahapan analisis.

Berdasarkan pada permasalahan yang terjadi saat melakukan wawancara dan observasi di SMK Negeri 7 Pontianak serta hasil penelitian [18], maka peneliti melakukan penelitian yang bertujuan mengembangankan media pembelajaran interaktif Perangkat Keras Komputer berbasis desktop, mulai dari tahapan analisis, desain, pengembangan, penerapan, sampai evaluasi.

\section{METODA}

Jenis penelitian yaitu penelitian dan pengembangan dengan pendekatan ADDIE. Pendekatan ADDIE meliputi Analysis, Design, Develop, Implement, serta Evaluate. ADDIE dipilih karena menggambarkan pendekatan yang sistematis untuk pengembangan instruksional.

Tahap analysis (analisis), meliputi analisis kebutuhan seperti analisis mata pelajaran, pengguna, materi dan media, serta saranaprasarana. Analisis mata pelajaran yaitu untuk menganalisis kelengkapan bahan ajar pada mata pelajaran Pengenalan Komponen Perangkat Keras Komputer. Analisis pengguna yaitu untuk menganalisis kebutuhan siswa terhadap media dalam pembelajaran. Analisis materi dan media yaitu untuk penyesuaian materi dengan media sesuai dengan kebutuhan siswa. Analisis saranaprasarana yaitu untuk menganalisis kebutuhan sarana serta prasarana untuk proses pembelajaran.

Tahap design (Desain) yang dilakukan meliputi desain materi, Garis Besar Isi Media (GBIM), storyboard, dan flowchart. Tahap develop (pengembangan) yang dilakukan adalah mengubah desain media pembelajaran menjadi sebuah program yang berisikan teks, suara, dan gambar dengan Visual Basic 6.0 serta Microsoft Access 2017 sebagai aplikasi database. Sebelum diterapkan, media pembelajaran yang dikembangkan divalidasi terlebih dahulu. Materi divalidasi 2 orang ahli dan media divalidasi 2 orang ahli. Tahap implement (penerapan) dilakukan terhadap kelompok kecil subjek penelitian berjumlah 20 siswa. Siswa kelas XA Jurusan TKJ SMK Negeri 7 Pontianak merupakan subjek dalam penelitian.

Tahap evaluate (evaluasi) merupakan tahapan untuk mengukur tingkat validitas dan kelayakan media. Materi divalidasi terkait aspek isi dan ketepatan media pembelajaran menggunakan angket lembar validasi. Validasi media terkait aspek media, tampilan, dan efektivitas media pembelajaran menggunakan angket lembar validasi. Respons subjek penelitian (siswa) terkait aspek tampilan, efektivitas, minat belajar, dan kemudahan belajar dengan angket respons.

Teknik dalam melakukan analisis data yaitu dengan statistik deskriptif. Langkah-langkahnya sebagai berikut.

1. Mengkuantitatifkan pilihan jawaban angket. 
Tabel 1. Kriteria penilaian

\begin{tabular}{|c|c|}
\hline Kriteria & Skor \\
\hline Sangat Setuju & 5 \\
Setuju & 4 \\
Kurang Setuju & 3 \\
Tidak Setuju & 2 \\
Sangat Tidak Setuju & 1 \\
\hline
\end{tabular}

2. Melakukan tabulasi data.

3. Melakukan perhitungan persentase.

$\mathrm{P}=\mathrm{S} / \mathrm{N} \times 100 \%$

Dimana $P$ adalah persentase dari sub-variabel, $S$ adalah jumlah skor pada setiap sub-variabel, dan $\mathrm{N}$ adalah jumlah maksimum dari skor yang diperoleh.

4. Melakukan transformasi ke dalam tabel. Dalam menentukan kriteria kuantitatif (persentase).

a. Tentukan persentase ideal dari skor yang diperoleh (skor maksimum yang diperoleh) $=100$ persen.

b. Tentukan persentase terendah dari skor yang diperoleh (skor minimum yang diperoleh) $=$ 20 persen.

c. Tentukan nilai range yang diperoleh, yaitu $100-20=80$.

d. Tentukan interval pada kategori, yaitu "Tidak Baik," "Kurang Baik," "Cukup," "Baik," dan "Sangat Baik."

e. Tentukan lebar dari interval dengan cara: 80 / $5=16$.

Berdasarkan langkah-langkah tersebut, maka hasil yang diperoleh dari kriteria persentase pada Tabel 2.

Tabel 2. Kriteria persentase

\begin{tabular}{|c|c|}
\hline Interval & Kategori \\
\hline $85 \%-100 \%$ & "Sangat Baik" \\
$69 \%-84 \%$ & "Baik" \\
$53 \%-68 \%$ & "Cukup" \\
$37 \%-52 \%$ & "Kurang Baik" \\
$20 \%-36 \%$ & "Tidak Baik" \\
\hline
\end{tabular}

\section{HASIL DAN PEMBAHASAN}

Melakukan pengembangan terhadap media pembelajaran interaktif pada materi Perangkat Keras Komputer merupakan tujuan penelitian dengan menggunakan model ADDIE. Prosedur ADDIE bersifat sistematik yang berarti setiap langkah atau tahapan pengerjaannya selalu berdasarkan pada hasil langkah atau tahapan sebelumnya yang telah dilakukan perbaikan. Hasil penelitian diuraikan sebagai berikut.

\section{A. Hasil Penelitian}

Berdasarkan pada model ADDIE, maka tahap pengembangan dalam penelitian yang dilakukan sebagai berikut.

\section{Analysis (Analisis)}

Analisis kebutuhan merupakan dasar pembuatan sebuah media atau program. Peneliti melaksanakan analisis kebutuhan saat melakukan wawancara dan observasi di awal pelaksanaan penelitian. Berdasarkan hasil wawancara dan observasi yang dilakukan, diperoleh informasi sebagai berikut.

a. Analisis Mata Pelajaran

Saat observasi dilakukan, peneliti melihat bahwa guru menyampaikan materi pelajaran di laboratorium komputer pada mata pelajaran produktif materi Pengenalan Perangkat Keras Komputer, terdapat beberapa kendala yang terjadi. Akibat dari kendala tersebut, siswa mengalami kejenuhan dikarenakan guru mengajar hanya dengan cara mejelaskan materi yang berisi teks dan gambar secara konvensional, sehingga materi yang disampaikan oleh guru sulit untuk diterima dengan baik oleh siswa. Siswa menjadi kurang menyukai mata pelajaran produktif. Siswa beranggapan bahwa mata pelajaran produktif adalah pelajaran yang susah untuk dipahami. Mengantisipasi kendala tersebut, media pembelajaran yang menarik perlu dikembangkan. Salah satunya adalah media pembelajaran interaktif Perangkat Keras Komputer berbasis desktop.

b. Analisis Pengguna

Peneliti melalukan pengembangan media pembelajaran yang interaktif untuk dapat digunakan oleh guru dan siswa. Pengembangan media pembelajaran harus sesuai dengan penggunanya.

c. Analisis Materi dan Media

Mata pelajaran produktif pada materi Pengenalan Perangkat Keras Komputer menjadi suatu hal yang sulit dipahami oleh siswa dibandingkan dengan materi lainnya. Hal tersebut dikarenakan pada materi Pengenalan Perangkat Keras Komputer siswa harus benar-benar mengenal bentuk, fungsi, dan kegunaan setiap komponen perangkat keras komputer tersebut. Apabila materi yang disampaikan tidak dibuat menggunakan media yang menarik, maka menyebabkan siswa sulit memahami materi yang disampaikan. Selama peneliti melakukan observasi, penyampaian materi oleh guru dengan menampilkan gambar serta menjelaskan secara konvensional dengan slide, sehingga sulit untuk dipahami siswa.

\section{d. Analisis Sarana-Prasarana}

Hasil wawancara dan observasi, guru mampu mengoperasikan laptop atau komputer dengan baik; LCD proyektor dan sound system di laboratorium komputer befungsi dengan baik. Berdasarkan hal tersebut, maka disimpulkan 
sarana-prasarana yang terdapat di sekolah tersebut memungkinkan untuk media pembelajaran yang interaktif digunakan dan diterapkan.

2. Design (Desain)

Desain dibuat berdasarkan hasil analisis kebutuhan yang meliputi desain materi, GBIM, storyboard, serta flowchart. Desain media bersifat konseptual dan menjadi dasar untuk pengembangan.

a. Desain Materi

Desain materi adalah alir atau bagan dari kompetensi pada materi Pengenalan Perangkat Keras Komputer. Penguraian secara rinci dan jelas terhadap materi ke bentuk pokok bahasan Pengenalan Perangkat Komponen Masukan (Input), Keluaran (Ouptput), Proses (Process), dan Penyimpanan (Storage). Materi tersebut dipilih menyesuaikan Standar Kompetensi dan Kompetensi Dasar Pengenalan Perangkat Keras Komputer. b. Desain GBIM

GBIM dikembangkan mengacu pada silabus dan RPP yang digunakan oleh guru. Isi dari GBIM yaitu tentang hal-hal yang akan ditampilkan pada media pembelajaran interaktif Perangkat Keras Komputer mata pelajaran Pengenalan Komponen Perangkat Keras Komputer. GBIM juga memuat tentang kompetensi dasar, indikator, serta rancangan tampilan yang disesuaikan dengan materi Perangkat Keras Komputer mata pelajaran Pengenalan Komponen Perangkat Keras Komputer sehingga terjadi kesesuaian isi materi dengan tujuan pembelajaran.

c. Storyboard

Deskripsi setiap tampilan yang menggambarkan objek multimedia dan juga perilaku dari setiap tampilan tersebut secara jelas terdapat pada storyboard. Storyboard yang didesain seperti pada Gambar 1.

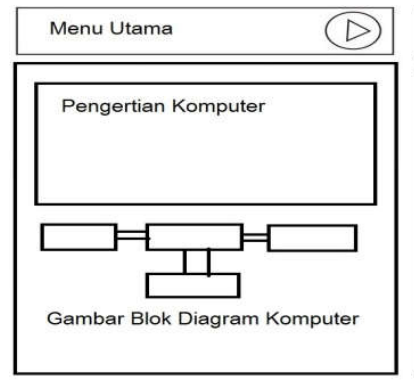

$(1.1)$

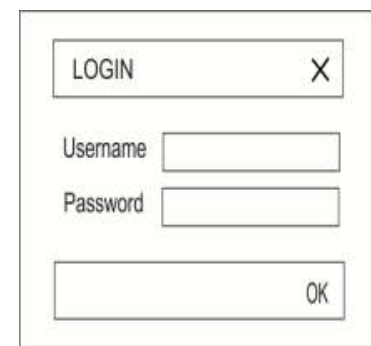

(1.5)

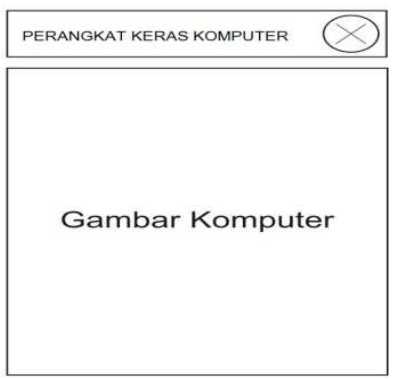

$(1.2)$

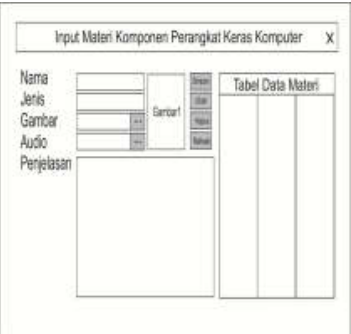

(1.6)

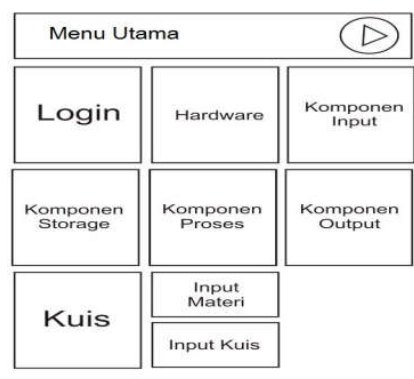

(1.3)

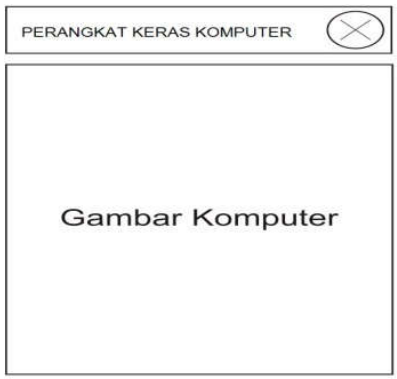

(1.4)

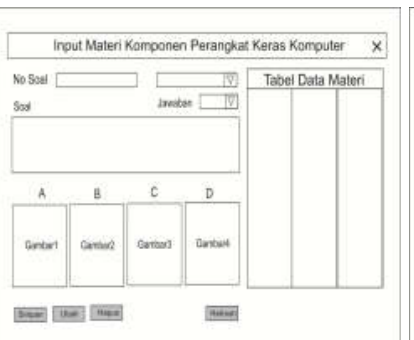

(1.7)

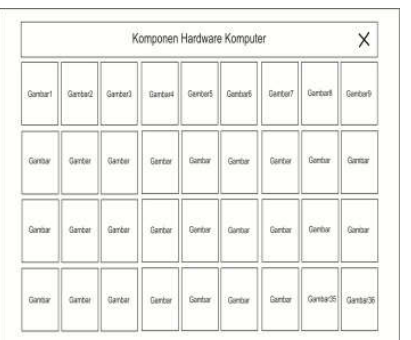

(1.8)

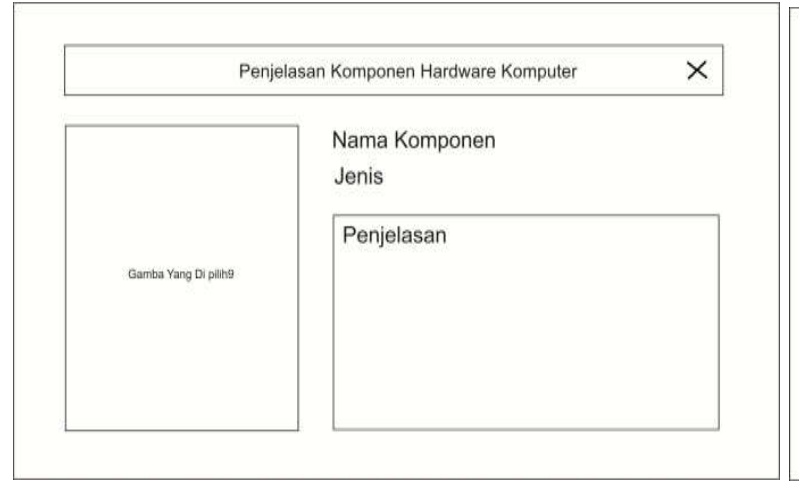

$(1.5)$

Gambar 1. Desain Storyboard

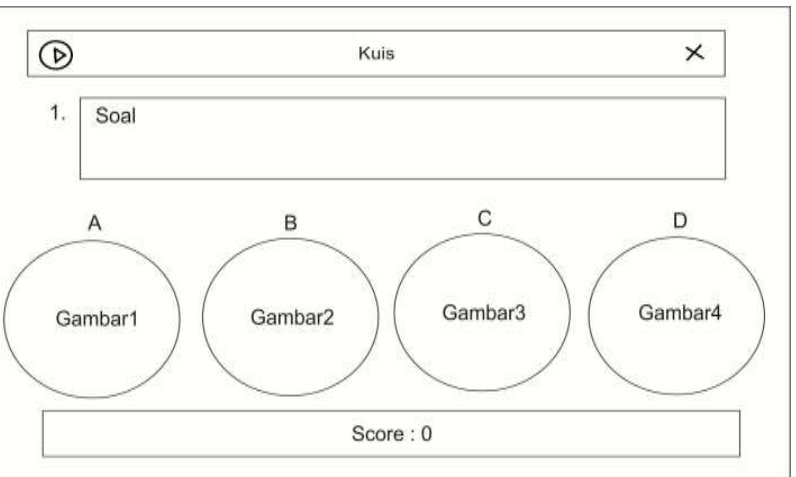

(1.6) 


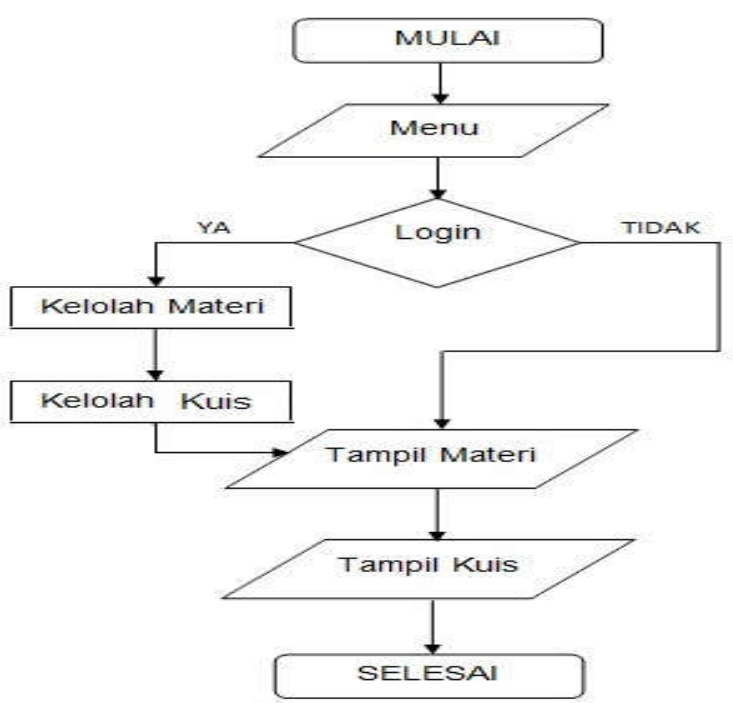

Gambar 2. Desain Flowchart

\section{d. Flowchart}

Sebelum mulai membuat media atau program, seseorang membuat perencanaan atau desain menggunakan simbol-simbol atau tanda-tanda khusus. Flowchart media pembelajaran interaktif Perangkat Keras Komputer seperti Gambar 2.

\section{Develop (Pengembangan)}

Validasi yang dilakukan menggunakan angket yang hasil akhirnya adalah rekomendasi validasi dan kelayakan terhadap media pembeljaran yang dikembangkan tersebut. Hasil pengembangan media pada Gambar 3.

4. Implement (Penerapan)

Implement merupakan proses penerapan media pembelajaran yang dikembangkan ke subjek penelitian. Di akhir pertemuan, subjek penelitian diberikan angket untuk mengukur tampilan, efektivitas, minat belajar, dan kemudahan belajar.

5. Evaluate (Evaluasi)

Evaluasi yang dilakukan terkait dengan hasil validasi materi dan media, serta respons siswa (subjek penelitian) terhadap penerapan media.

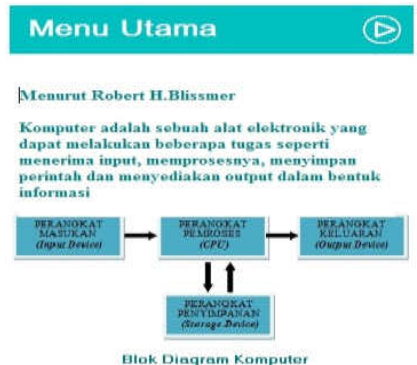

(3.1)

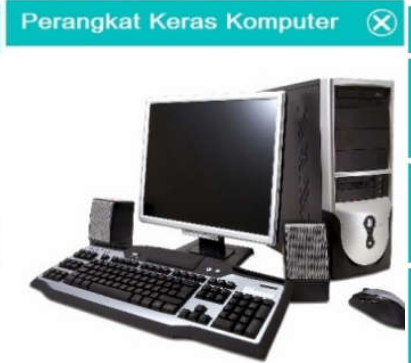

(3.2)

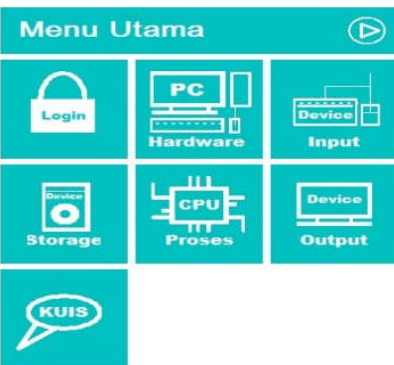

(3.3)

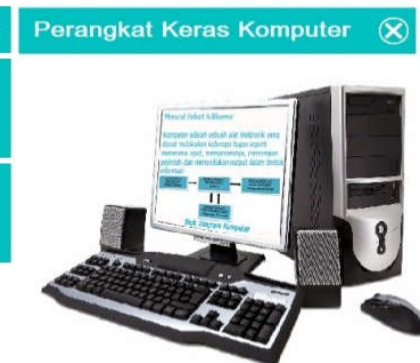

(3.4)

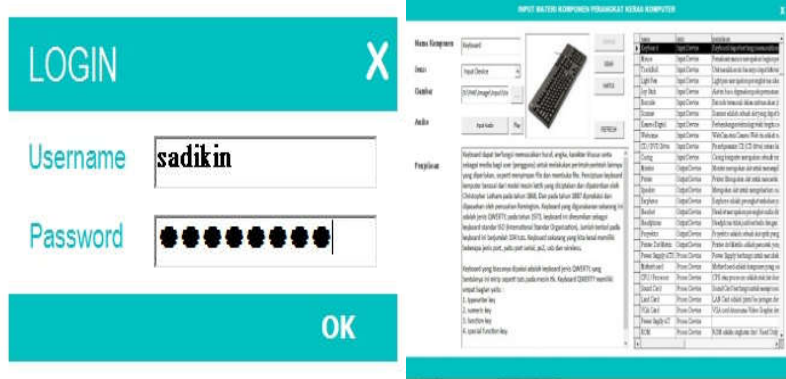

(3.5)

(3.6)

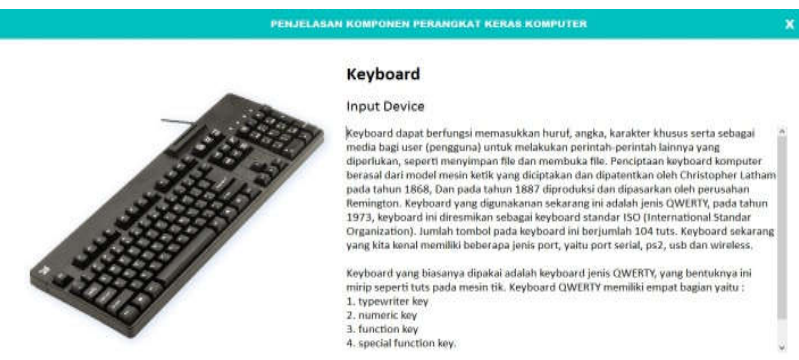

(3.9)

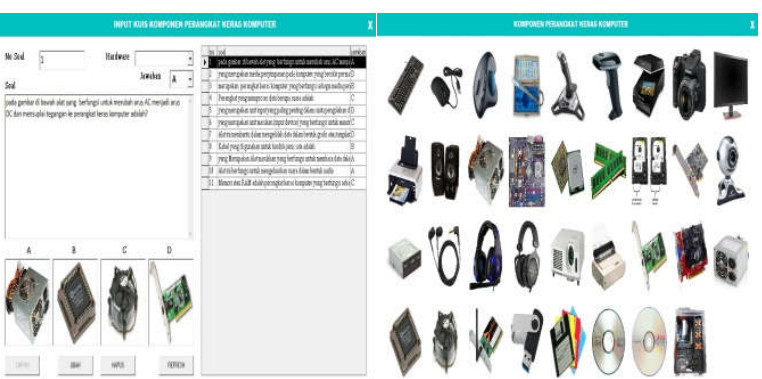

(3.7)

(3.8)

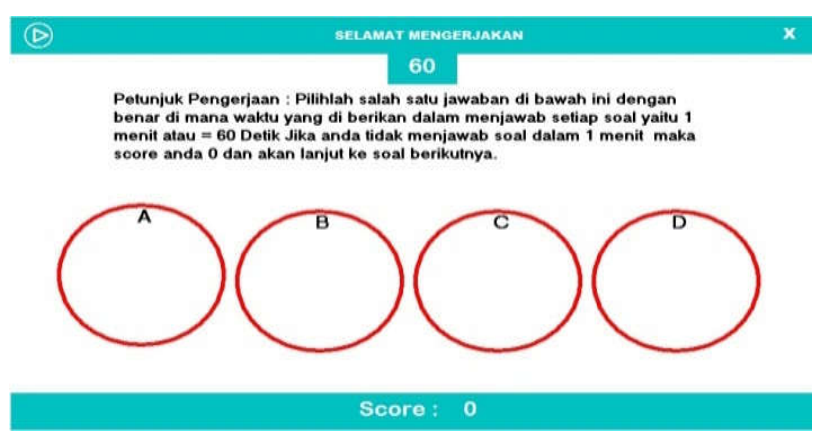

(3.10)

Gambar 3. Desain Storyboard 
a. Validasi Materi

Validasi dilakukan terhadap materi menggunakan angket validasi untuk menilai aspek isi dan ketepatan media pembelajaran. Hasil validasi ahli materi di Tabel 3 .

Tabel 3. Hasil validasi materi

\begin{tabular}{|c|c|c|c|c|}
\hline $\begin{array}{c}\text { Penilaian } \\
\text { Aspek }\end{array}$ & $\begin{array}{c}\text { Skor } \\
\text { Maks. }\end{array}$ & $\begin{array}{c}\text { Rerata Skor } \\
\text { Validator }\end{array}$ & $\%$ & Kategori \\
\hline Isi & 70 & 67,5 & 96,43 & $\begin{array}{c}\text { "Sangat } \\
\text { Baik" } \\
\text { "Sangat } \\
\text { Baik" }\end{array}$ \\
\hline
\end{tabular}

b. Validasi Media

Validasi dilakukan terhadap media menggunakan angket validasi dengan aspek penilaian: media, tampilan, dan efektivitas media. Hasil validasi ahli media di Tabel 4.

Tabel 4. Hasil validasi media

\begin{tabular}{|c|c|c|c|c|}
\hline $\begin{array}{c}\text { Penilaian } \\
\text { Aspek }\end{array}$ & $\begin{array}{l}\text { Skor } \\
\text { Maks. }\end{array}$ & $\begin{array}{c}\text { Rerata Skor } \\
\text { Validator }\end{array}$ & $\%$ & Kategori \\
\hline Media & 70 & 62,0 & 88,57 & $\begin{array}{l}\text { "Sangat } \\
\text { Baik" }\end{array}$ \\
\hline Tampilan & 60 & 52,5 & 87,50 & $\begin{array}{l}\text { "Sangat } \\
\text { Baik" }\end{array}$ \\
\hline Efektivitas & 90 & 81,0 & 90,00 & $\begin{array}{l}\text { "Sangat } \\
\text { Baik" }\end{array}$ \\
\hline
\end{tabular}

\section{c. Respons Siswa}

Respons siswa diperoleh berdasarkan angket yang diberikan ke siswa di akhir pembelajaran pada saat media pembelajaran interaktif yang dikembangkan diterapkan pada kelompok kecil subjek penelitian yang berjumalh 20 orang siswa. Angket respons terdiri atas aspek tampilan dan efektivitas. Data hasil respons siswa di Tabel 5.

Tabel 5. Respons siswa terhadap Media

\begin{tabular}{|c|c|c|}
\hline Aspek & Persentase & Kategori \\
\hline Tampilan & $90,83 \%$ & 'Sangat Baik' \\
Efektivitas & $88,78 \%$ & 'Sangat Baik' \\
Minat belajar & $90,83 \%$ & 'Sangat Baik' \\
Kemudahan & $88,78 \%$ & 'Sangat Baik' \\
belajar & & \\
\hline
\end{tabular}

\section{B. Pembahasan}

Ahli materi melakukan validasi terkait aspek isi dan ketepatan. Penilaian aspek isi masuk kategori "Sangat Baik" dengan nilai 96,43 persen. Dengan demikian telah tercapai tujuan pembelajaran menggunakan media yang dikembangkan. Aspek ketepatan masuk kategori "Sangat Baik" dengan nilai 90,00 persen. Dengan demikian pengembangan media sudah tepat serta terdapat kesesuaian dengan kurikulum pembelajaran. Materi ajar dalam media yang digunakan dalam pembelajaran harus sesuai kurikulum yang digunakan dan memiliki berbagai manfaat [19].

Alhli media melakukan validasi terkait aspek media, tampilan, dan efektivitas. Penilaian aspek media masuk kategori "Sangat Baik" dengan nilai 88,57 persen; aspek tampilan masuk kategori "Sangat Baik" dengan nilai 87,50 persen; serta aspek efektivitas masuk kategori "Sangat Baik" dengan nilai 90,00 persen. Berdasarkan validasi materi dan media oleh para ahli tersebut, disimpulkan pengembangan media valid dan layak diterapkan karena semua aspek penilaian masuk kategori "Sangat Baik" [20-21].

Hasil respons siswa diperoleh dengan angket respons yang disebarkan kepada siswa sebagai subjek penelitian di akhir proses pembelajaran yang menerapkan media pembelajaran interaktif Perangkat Keras Komputer. Respons yang diberikan terkait aspek tampilan, efektivitas, minat belajar, dan kemudahan belajar. Berdasarkan hasil respons siswa tersebut, media pembelajaran yang interaktif pada materi Perangkat Keras Komputer masuk kategori "Sangat Baik," sehingga siswa setuju media media tersebut diterapkan dalam proses pembelajaran [22-23].

\section{KESIMPULAN}

Proses pengembangan media pembelajaran yang interaktif berbasis desktop pada materi Perangkat Keras Komputer berhasil dengan menggunakan model pengembangan ADDIE. Hasil validasi ahli materi untuk aspek isi dan ketepatan berada pada kategori "Sangat Baik." Validasi yang dilakukan ahli media terkait aspek media, tampilan, dan efektivitas berada pada kategori "Sangat Baik." Berdasarkan validasi meteri dan media oleh para ahli tersebut, maka disimpulkan media yang dikembangkan valid dan layak diterapkan untuk proses pembelajaran. Respons siswa terhadap media pembelajaran yang diterapkan pada proses pembelajaran untuk aspek tampilan, efektivitas, minat belajar, dan kemudahan belajar, nilai yang diperoleh pada kategori "Sangat Baik."

\section{DAFTAR PUSTAKa}

[1] Ramadhani, M., Gafari, M.O.F., and Marice. (2019). Development of interactive learning media on material writing short story texts based on experience. Budapest International Research and Critics in Linguistics and Education, 2 (1), 91-102. 
[2] Lin, M.H., Chen, H.C., and Liu, K.S. (2017). A study of the effects of digital learning on learning motivation and learning outcome. Eurasia Journal of Mathematics Science and Technology Education, 13 (7), 3553-3564.

[3] Puspitarini, Y.D., Akhyar, M., and Djono. (2019). Development of video media based on Powtoon in social sciences. International Journal of Educational Reasearch Review, 4 (2), 198205.

[4] Mudinillah, A. (2019). The development of interactive multimedia using Lectora Inspire application in Arabic Language learning. Jurnal Iqra' : Kajian Ilmu Pendidikan, 4 (2), 285-300.

[5] Kuswari, H.I., Muryani, C., and Nugraha, S. (2019). The learning media development of interactive multimedia based e-learning to improve students' learning outcome and spatial thinking ability of X IIS students in SMA Negeri 3 Sragen in the academic year of 2017/2018. GeoEco Journal, 5 (1), 92-104.

[6] Rahayu, D.M., Roesminingsih, M.V., Harmanto, and Subroto, W.T. (2019). The use of interactive multimedia to improve critical thinking skills of primary school students. International Journal of Scientific and Research Publication, 9 (4), 138144.

[7] Munir, A., Lubis, M.R., and Ginting, R.L. (2019). Design and development of interactive learning media based on contextual teaching learning (CTL) in the subject of Evaluation and Supervision of Guidance and Counseling. Journal of Community Service and Research, 3 (1), 1-4.

[8] Amaliah, N., Daulay, S., and Gafari, M.O.F. (2018). Interactive multimedia development in teaching Drama for students class XI Senior High School 4 Medan. International Journal of Education, Learning and Development, 6 (8), 6170.

[9] Departemen Pendidikan Nasional. (2014). Kurikulum tingkat satuan pendidikan. Jakarta: Depdiknas.

[10] Sulfemi, W.B. (2019). Model pembelajaran kooperatif Mind Mapping berbantu audio visual dalam meningkatkan minat, motivasi dan hasil belajar IPS. Jurnal Pendidikan Ilmu Pengetahuan Sosial Indonesia, 4 (1), 13-19.

[11] Sulfemi, W.B. and Mayasari, N. (2019). Peranan model pembelajaran Value Clarification Technique berbantuan media audio visual untuk meningkatkan hasil belajar IPS. Jurnal Pendidikan, 20 (1), 53-68.

[12] Asmara, A.P. (2015). Pengembangan media pembelajaran berbasis audio visual tentang pembuatan koloid. Jurnal Ilmiah DIDAKTIKA, 15 (2), 156-178.

[13] Fikriyah, M., Indrawati, and Gani, A.A. (2015). Model Pembelajaran Berbasis Proyek (Project Based Learning) disertai media audio-visual dalam pembelajaran Fisika di SMAN 4 Jember. Jurnal Pembelajaran Fisika, 4 (2), 181-186.

[14] Ananda, R. (2017). Penggunaan media audio visual untuk meningkatkan hasil belajar Pendidikan Kewarganegaraan siswa kelas IV SD Negeri 016 Bangkinang Kota. Jurnal BASICEDU, 1 (1), 21-30.

[15] Yusup, M., Aini, Q., and Pertiwi, K. (2016). Media audio visual menggunakan Videoscribe sebagai penyajian informasi pembelajaran pada kelas Sistem Operasi. Technomedia Journal, 1 (1), 126-138.

[16] Nomleni, F.T. and Manu, T.S.N. (2018). Pengembangan media audio visual dan alat peraga dalam meningkatkan pemahaman konsep dan pemecahan masalah. SCHOLARIA: Jurnal Pendidikan dan Kebudayaan, 8 (3), 219-230.

[17] Wirdaningsih and Mardhatillah. (2016). Penerapan media audio-visual terhadap keaktifan pada materi Hubungan antara Sumber Daya Alam dengan Lingkungan siswa kelas IV SD Negeri Pasi Teungoh Kecamatan Kaway XVI. Bina Gogik: Jurnal Ilmiah Pendidikan Guru Sekolah Dasar, 3 (2), 1-14.

[18] Sophia, A. and Yensasnidar. (2019). Androidbased interactive learning media validity in Genetic Subtance and Synthesis Protein for students of Medical Laboratory Technology (TLM). International Journal of Progressive Sciencies and Technologies (IJPSAT), 16 (1), 123-126.

[19] Daryanto. (2010). Media Pembelajaran. Yogyakarta: Gava Media.

[20] Qamariah, W., Daningsih, E., and Yokhebed. (2017). Kelayakan animasi Stop Motion pembuatan cake pepaya submateri Peran Tumbuhan di bidang ekonomi. Jurnal Pendidikan Informatika dan Sains, 6 (2), 267-279

[21] Faramita, G., Daningsih, E., and Yokhebed. (2018). Kelayakan film dokumenter pembuatan bingka pepaya submateri Peran Tumbuhan di bidang ekonomi. Edukasi: Jurnal Pendidikan, 16 (2), 267-280.

[22] Mustika, Daningsih, E., and Marlina R. (2018). Kelayakan video Organ Tumbuhan di kelas XI SMA. Edukasi: Jurnal Pendidikan, 16 (2), 222234.

[23] Koriaty, S. and Manggala, E. (2016). Penerapan media e-book terhadap minat belajar siswa di kelas X Jurusan TKJ SMK Negeri 4 Pontianak. Jurnal Pendidikan Informatika dan Sains, 5 (2), 237-246.

\section{Biodata Penulis}

Muhamad Arpan, gelar Sarjana Komputer diperoleh dari STMIK Pontianak Program Studi Sistem Informasi tahun 2009 dan gelar Magister Pendidikan diperoleh dari Universitas Negeri Yogyakarta Program Studi Pendidikan Teknologi 
dan Kejuruan Konsentrasi Pendidikan Information and Communication Technology tahun 2014. Pengajar di Program Studi Pendidikan Teknologi Informasi dan Komputer IKIP PGRI Pontianak.

Sadikin, penulis lahir di Pontianak dan memperoleh gelar Sarjana Pendidikan (S.Pd.) dari
IKIP PGRI Pontianak Program Studi Pendidikan Teknologi Informasi dan Komputer Fakultas Pendidikan MIPA dan Teknologi pada tahun 2017. Penulis merupakan seorang pegawai swasta yang bergerak di bidang teknologi. 